\title{
A comparative approach to national innovative capacity in the long-run: Spain between Europe and Latin America
}

\author{
José M. Ortiz-Villajos \\ Department of Applied and Structural Economics and History, \\ Faculty of Economics, \\ Complutense University of Madrid, \\ 28223 Pozuelo de Alarcón, Madrid, Spain \\ Email: jmortizv@ucm.es
}

\begin{abstract}
This article explores the evolution of the Spanish innovative capacity from the 19th century to the present day compared to some countries in Western Europe and Latin America. To this end, three indicators have been used: patents granted in the USA, domestic patent applications in each country, and scientific publications. The first appears to be, within its limitations, the best measure of national innovative capacity, although the other two provide valuable complementary information. The study reveals that Spain has significantly improved its innovative capacity over time, although it still lags far behind the most innovative countries. On the other hand, Argentina and Mexico were ahead of Spain in the first half of the twentieth century, but today Spain has an innovative capacity several times greater than that of the two Latin American countries. In fact, Argentina and Mexico seem to have reversed their innovative capacity over time.
\end{abstract}

Keywords: innovative capacity; patents; scientific publications; Spain; Europe; Latin America.

Reference to this paper should be made as follows: Ortiz-Villajos, J.M. (xxxx) 'A comparative approach to national innovative capacity in the long-run: Spain between Europe and Latin America', Int. J. Technological Learning, Innovation and Development, Vol. X, No. Y, pp.xxx-xxx.

Biographical notes: José M. Ortiz-Villajos is a $\mathrm{PhD}$ in Economics and Associate Professor in the Department of Applied and Structural Economics and History at Complutense University of Madrid. His research interests deal with innovation, patents and economic development in the long run.

This paper is a revised and expanded version of a paper entitled 'La capacidad innovadora española del siglo XIX a la actualidad: una aproximación' presented at XII Congreso Internacional de la Asociación Española de Historia Económica, Salamanca, Spain, 6-9 September 2017.

\section{Introduction}

Since the seminal contribution of Schumpeter (1934), a multitude of theoretical, empirical and historical studies (e.g., Solow, 1957; Landes, 1969; Mokyr, 1990; Romer, 1990; Porter, 1990, etc.) have been showing in various ways the close relationship 
between innovation and economic development. Some even claim that the engine of long-term growth is technology [Grossman and Helpman, (1991), p.18]. In any case, it seems unquestionable that it is one of the main determinants of economic progress. In the Spanish case, there is evidence that its low technological level has contributed to its relative economic backwardness in modern times (e.g., López and Valdaliso, 1997; Cebrián Villar, 2001; Ortiz-Villajos, 2004, 2009; Prados-de-la-Escosura and Rosés, 2009; Cubel et al., 2012). Therefore, understanding how technology is created or increased is key to explaining differences in wealth between countries and how to reduce them. This requires obtaining some kind of measurement of the national technological level to subsequently investigate the factors that determine it.

The process of creating and increasing technological capacity is gradual and complex, as is evident, for example, in the essay by Mokyr (2002) on the formation of useful knowledge that led to the Industrial Revolution. In the field of innovation and development studies there is a current that seeks to identify and quantify the determinants of technological or innovative capacity (e.g., Lall, 1992; James and Romijn, 1997; Narula, 2004). In this line, Furman et al. (2002) analyse the determining factors of what they call 'national innovative capacity' through a sample of seventeen OECD countries in the period 1973-1996. The study includes a wide variety of factors (human capital, R\&D investment, economy size, commercial and intellectual property policies, etc.) previously identified by the traditions of endogenous growth (Romer, 1990), competitive advantage (Porter, 1990) and national innovation systems (Nelson, 1993). They measure the national innovative capacity essentially by the number of patents per inhabitant granted in the USA, considered the best of the available indicators [Furman et al., (2002), p.909]. However, they also explore three others: scientific publications, the market share of high-tech industries, and Total Factor Productivity (Ibid., pp.912-913).

It is obvious that there is no perfect indicator of innovative capacity. The one used by Furman et al. (2002), with all its limitations, has the advantage of being clear and of supporting international comparison better than others. ${ }^{1}$ An alternative proposal is to calculate an index composed of several indicators. This has the advantage of being a more complete measure and the disadvantage of being less clear. Archibugi and Coco (2005) offer a good explanation of the characteristics of these composite indices and an overview of studies based on them to measure technological capacity.

The objective of this work is to provide a first approach - general and descriptive - to the evolution of Spanish innovative capacity from the mid-19th century to the present day. To assess the country's performance in this regard, we will compare it with the other four major countries of Western Europe (France, Germany, Italy and the UK) on the one hand, and with two relevant Latin American countries (Argentina and Mexico) on the other. In terms of income, the European group belongs to the most developed world, the two Latin American nations, to the developing world, and Spain is in the middle. Therefore, the study will also shed some light on the relationship between innovative capacity and economic development.

One of the main problems of long-term studies is the availability of data. In this work, the difficulty of measuring the innovative capacity itself is also added. In any case, we have been able to obtain three of the indicators used by the mentioned studies with the necessary temporal perspective. Fortunately, the best indicator of national innovative capacity according to Furman et al. (2002), patents granted in the USA, is available since the 19th century. The same goes for scientific publications, also used by those authors. Another indicator that can be considered as a reflection of the national innovative 
capacity and which is also available since the 19th century is the number of resident patents applied for in each country. The latter has been used by Desai et al. (2002) to build its technology achievement index, which was included by the United Nations in the Human Development Report (UNDP, 2001). In summary, the data on the three indicators mentioned - patents granted in the USA, those of residents in each country, and the number of scientific publications - from the 19th century to the present day, all in per capita terms, are the basis of the present study.

After this introduction, the following three sections analyse each of the three mentioned indicators respectively - first for the Spanish case, and then for the European and Latin American ones, and Section 5 concludes and provides some policy implications.

\section{Patents granted in the USA}

The first indicator that will be analysed is the number of patents granted by the mentioned countries in the USA per million inhabitants. ${ }^{2}$ The difficulty to obtain a patent in that country, greater for foreigners, discourages the application of patents based on not really new ideas or of low value. So there is some guarantee that the patents granted in the USA reflect a true innovative effort. ${ }^{3}$ In addition, given the size, the international weight, and the high technological level of the American economy, presumably the valuable and cutting-edge innovations from any place will tend to be patented there. These are some of the arguments in favour of using the patents registered in the USA to measure the countries' innovative capacity. ${ }^{4}$ But this measure is not perfect, among other things because it is affected by the intensity of the bilateral trade and because it excludes non-patented innovations. ${ }^{5}$ Hence, it must not be forgotten that it is a limited indicator.

According to the previous comments, Figure 1 would represent only an approximate view of the evolution of the Spanish innovative capacity from 1883 to 2009. Taking this into account, a first evidence shown by the data is that such capacity would have multiplied by a factor of 21 throughout those 126 years, as the country passed from obtaining 0.3 patents per million inhabitants on average in the three-year period 1883-1885 to 6.5 in 2007-2009. Other evidence is that this improvement has not followed a linear trend but has taken place with noticeable ups and downs. In particular, the figure shows by and large three phases of expansion in the innovative capacity (1883-1930; 1943-1975; 1983-2000) and three of decline (1931-1942; 1976-1982; 2001-2007). The latter three coincide respectively with the Great Depression and subsequent wars, ${ }^{6}$ the oil crisis, and the dot-com bubble. But if the expansionist phases are looked in detail, several shorter fluctuations are observable. For instance, the innovative capacity seemed to increase in the years between the 19th and 20th centuries and stagnate during the First World War, which coincides with previous findings on the Spanish economy (Maluquer-de-Motes, 1987). In the following phase, the innovative capacity increased in the 1940s and in the 1960s, whereas it was stagnated in the 1950s. The expansion observed in the 1940s differs from the usual view of that period (López and Valdaliso, 2001; Deu and Llonch, 2013), although it agrees with some recent contributions highlighting certain technological dynamism in those years (Camprubí, 2014; Virós, 2013; Fernández Pérez et al., 2019). No doubt, the evidence provided is insufficient, but invites to look into the innovation activity in the "40s with more detail; 
but also of the ' $50 \mathrm{~s}$, usually considered a dynamic period, contrary to what the patents granted in the USA apparently indicate. Lastly, the rapid and continuous expansion from 1983 to 2000, with the only interruption of the early 1990s crisis, coincides with a period of considerable economic growth in Spain. To sum up, with its limitations, our first indicator suggests that the Spanish innovative capacity evolved in parallel - with the mentioned exceptions - with the country's economic development. The other two indicators (the patents filed by residents, and the scientific publications) will qualify and complement this view. But before that, to evaluate the observed Spanish progress regarding the just analysed indicator, it is necessary to place it in the international context.

Figure 1 Patents granted in the USA to residents in Spain per million inhabitants, 1883-2009

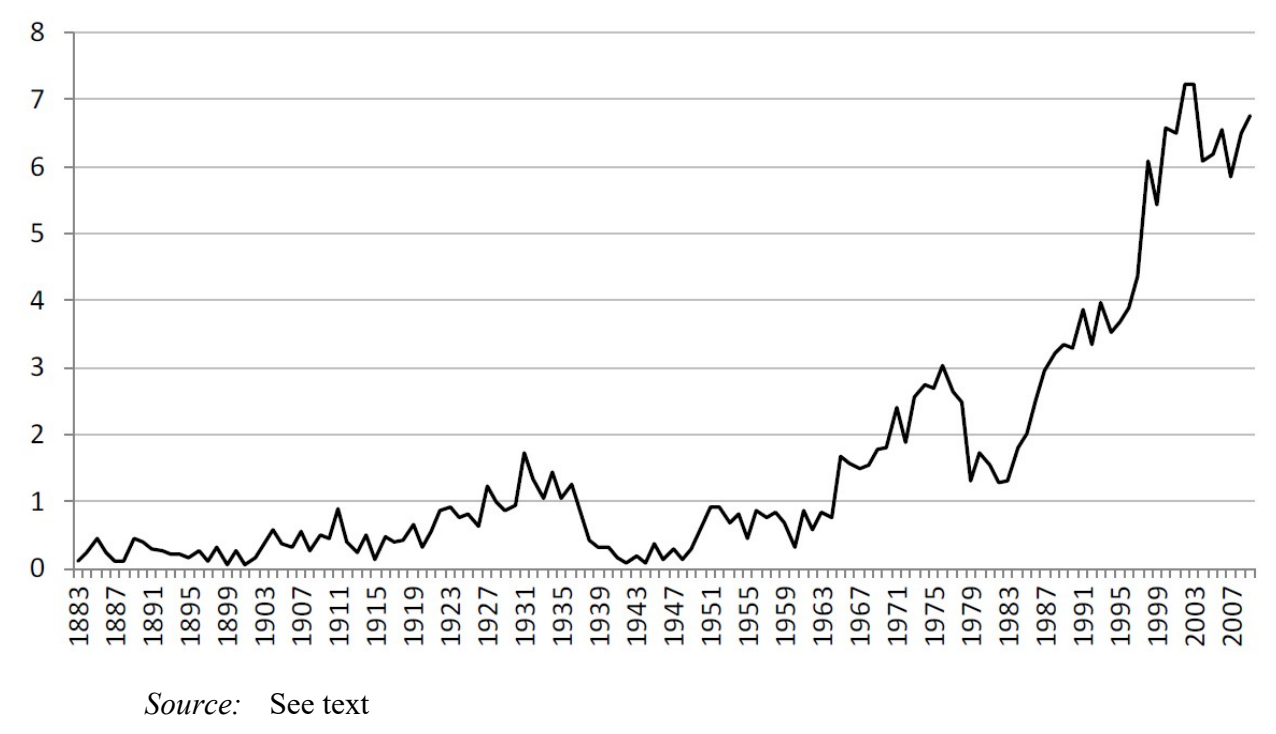

With the reservations mentioned above, Figure 2 would reflect the evolution of the innovative capacity of the five Western European countries represented there from 1883 to 2009. According to this, it is obvious that Spain, in spite of its undeniable progress (Figure 1), has maintained throughout the whole period a very low level compared to that of the UK, Germany and France, and to the Italian one since $1950 .^{7}$ The differences are overwhelming because, according to this indicator, Germany today would have an innovative capacity about 20 times higher than the Spanish one; the UK and France, approximately ten times larger; and Italy, about four times. With some fluctuations (without taking into account the anomalous years of the Second World War), the Spanish backwardness compared to the former three countries has maintained in similar levels since 1883 to this day. That is, Spain has been historically and still is today a very backward country in terms of innovative capacity. This has not prevented it to approach the income level of the most developed countries (Maddison, 2001), although it is probably the main reason why still it has not catch up with them; this not being possible unless the country improves its technological level.

However, although Spain is clearly behind the leader countries in innovation, in the world context it occupies a relatively advanced position. Of course, there is no reason to be satisfied with this as the model of reference in this aspect must be the group at the 
head; but it is neither reasonable to ignore it because it is one of the causes of the relatively high income level achieved by this Southern European nation. In this respect, the comparison with Argentina and Mexico - two Latin American countries with strong historical ties with Spain - can be illustrative.

Figure 2 Patents granted in the USA to residents in five Western European countries per million inhabitants, 1883-2009

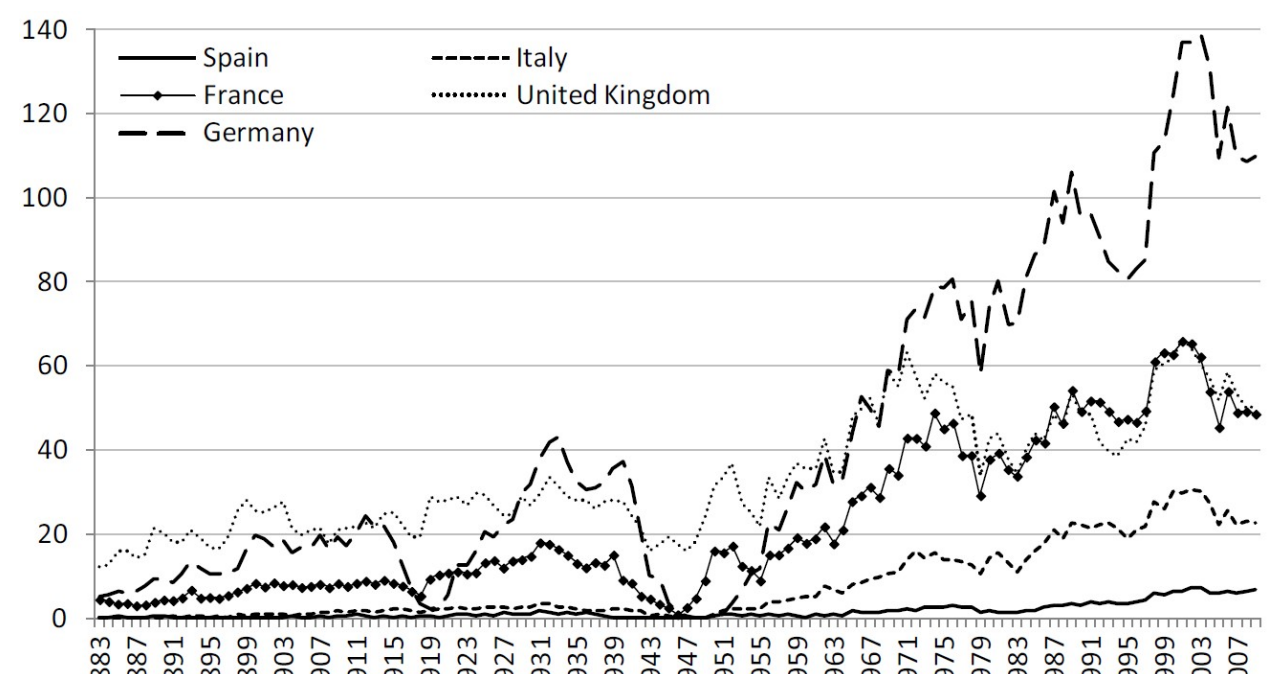

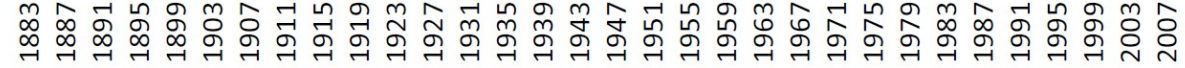

Source: See text

Figure 3 Patents granted in the USA to residents in Argentina, Mexico and Spain per million inhabitants, 1883-2009

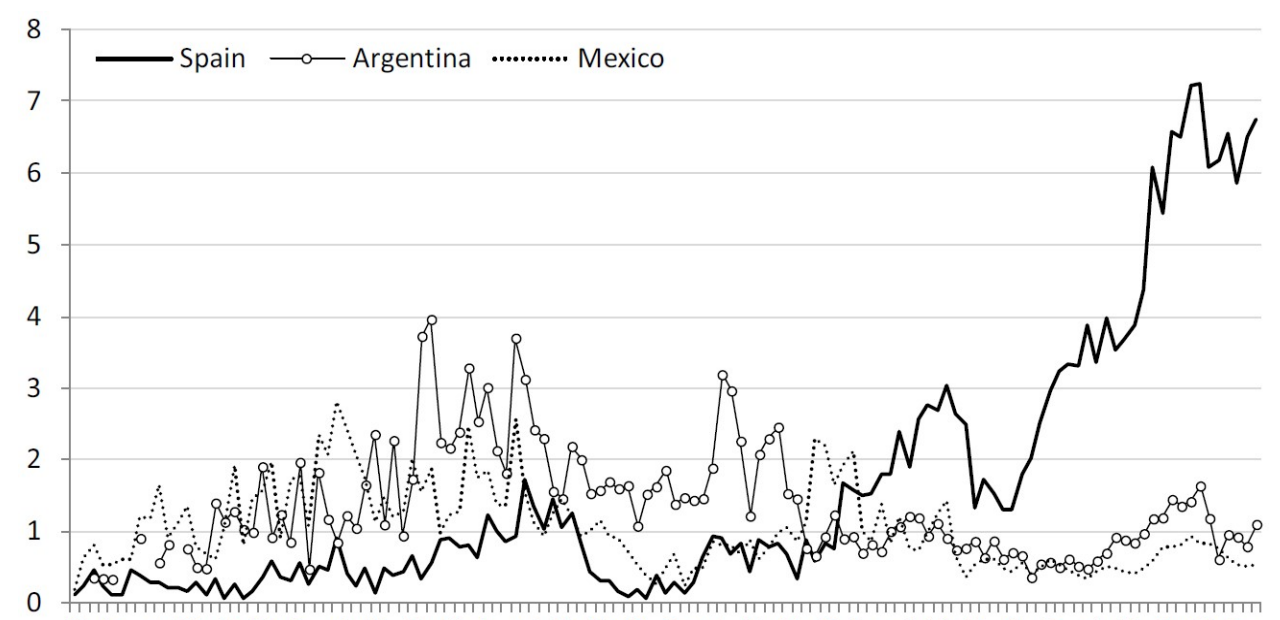

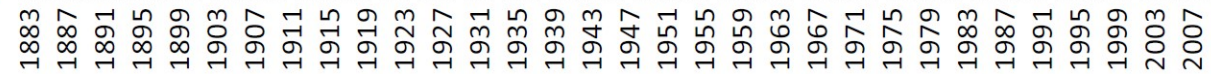

Source: See text 
According to the number of patents per capita granted in the USA (Figure 3), Argentina, Mexico and Spain had a similar innovative capacity about 1883, but since then the two Latin American countries progressed more rapidly and surpassed Spain up to the Great Depression of the 1930s. From then to 1960, Argentina was clearly ahead of Spain and Mexico. But from then onwards, Spain progressed rapidly, while the two Latin American countries fell apart. As a result, Spain has today an innovative capacity seven times as large as that of Argentina and Mexico. It is true that patents may not be a good indicator of the innovative capacity of developing countries, as several authors have pointed out [e.g., Bell and Figueiredo, (2012), pp.52-54; Kruss, 2018], but they tell us something about their ability to innovate in advanced technology, however small. Therefore, the evolution of this indicator over time can, at least, provide a certain idea of the trend of each country's advanced innovative effort. So, according to Figure 3, Argentina and Mexico seem to be in a relatively worse situation today in this respect than in the first third of the 20th century, unlike Spain. This has probably something to do with the relative reversal of fortunes of these countries between the beginning and the end of the 20th century. ${ }^{8}$ The improvement of the innovative capacity in the long run requires consistent policies and investments as well as a propitious institutional environment, which Spain - with all its limitations - has been strengthening since mid-20th century. However, the other two nations seem to have spoiled from then onwards the innovative environment that apparently were developing at the end of the 19th century and the beginning of the 20th. The explanation of this, which exceeds the object of the present paper, must be looked for in the complex economic and institutional history of those countries. ${ }^{9}$

\section{Patents filed by residents in their country}

As has been said, another plausible indicator of the national innovative capacity is the number of patents per capita filed by residents in each country. ${ }^{10}$ Those applied for by non-residents are not taken into account because, although they can be a way to transfer technology, they are the result of innovation activities accomplished outside the country. On the contrary, the patents registered in the country of residence usually result from indigenous innovative effort. It is certain that an invention could be developed in a country and patented in another, but this is not a real problem because the usual procedure is that inventors/firms patent their inventions firstly in their own country and later on - if it is economically worthwhile - in other ones. More problematic is when a resident patentee serves as a mere intermediary of a foreign inventor, because in that case the site of residence does not coincide with that of the origin of the technology. In fact, these cases are not rare. ${ }^{11}$ But standard patent statistics do not distinguish them, so we have to settle for the available data; namely, the patents filed by residents in each country. With its limitations, it can be taken as a rough measure of the domestic innovative capacity. Besides, compared to the previous indicator, this one has the advantage of including all patents generated by the national innovation system and not only part of them (those granted as well in the USA). A disadvantage is that it does not discriminate between more and less valuable patents contrary to the previous one. Hence, rather than alternative, the two indicators can be seen as complementary. 
Figure 4 Domestic patent applications in Spain per million inhabitants, 1883-2015

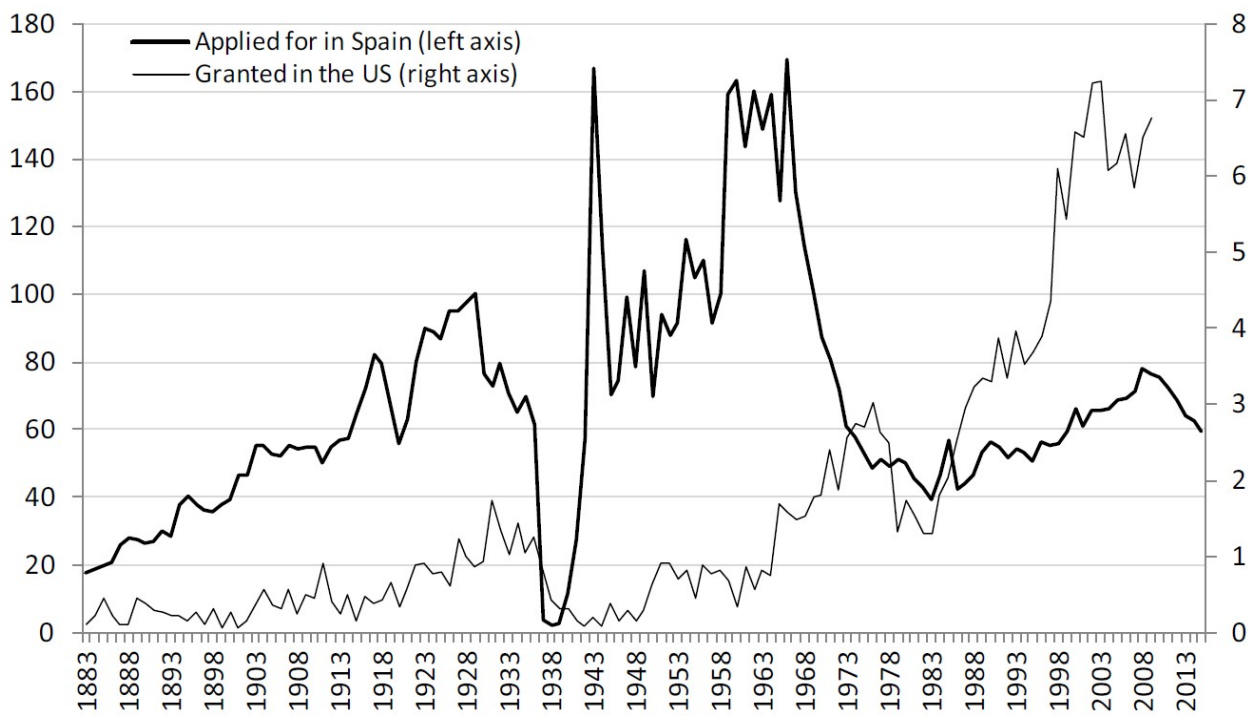

Source: See text

Figure 4 shows the evolution of the second indicator (the patents applied for in Spain by residents in the country per million inhabitants) from 1883 to 2015 . The previous indicator (the patents granted to Spaniards in the USA) has been superimposed in the figure to facilitate comparisons between them. It is obvious, first of all, the great difference in order of magnitude between the two variables: approximately 100 to 1 until the 1960 s and 20 to 1 thereafter. That is, up to 1960 Spaniards registered in the USA, in per capita terms, $1 \%$ of the patents they filed in Spain, and since that decade onwards, $5 \%$ of them. This noticeable rise was due both to the great increase of patents granted to Spaniards in the USA since the 1960s and to the collapse of domestic applications in Spain since 1966. But in spite of their great divergence in quantity, the two indicators have evolved over time in a similar fashion. Indeed, by and large, both of them show an increasing trend up to the Great Depression, ${ }^{12}$ a resumption of growth in the early 1940s which lasts up to about the oil crisis, and a new recovery from the 1980s up to the 2008 crisis. The considerable negative effect of the latter is only observable in the series of patents filed in Spain as for those years we do not have consistent data on the patents granted in the USA (vid. supra), although they probably have decreased.

Together with the mentioned coincidences, Figure 4 shows as well some clear differences in the evolution of the two variables. One of them is that the patents filed in Spain recovered the 1930 level much earlier (c. 1945) ${ }^{13}$ than those granted in the USA (c. 1965). In addition, the applications in Spain showed a strong dynamism in the 1950s contrary to the stagnation observed for patents granted in the USA in that decade. However, the drop of the domestic applications in Spain that commenced in 1966 was previous and deeper than that observed in the patents granted in the USA since 1976. In both cases, the recovery began in 1983, but with different outcomes: while the patents granted in the USA increased rapidly to reach their highest level of all time at the beginning of the 21 st century, the national applications in Spain have not recovered the maximum level reached in 1966. 
The drastic drop in national patents from those years was not an exclusive phenomenon of Spain but international, which probably had to do mainly with a reduction in the propensity to patent. That is to say, this striking change would not have occurred so much because of a decrease in innovative capacity but because of a modification in the use of the patent system by the inventors due to several factors (Gilfillan, 1964). That turning point would have occurred in Spain in the mid-1960s, but in more developed countries it took place previously, as we will see below. A consequence of this is that the levels of this indicator before and after that change would not be comparable. This is one of the limitations of this variable as a measure of long-term inventive activity (Gilfillan, 1964; Sanders, 1962; Schmookler, 1966). Despite this, Schmookler (1962) has shown that fluctuations in the number of patents in the short/medium term are a good reflection of the evolution of inventive activity. In addition, this and another more critical author such as Sanders (1962) agree that the analysis of patent data is essential to understand many aspects of the innovative activity.

Figure 5 Domestic patent applications in five European countries per million inhabitants, 1883-2015

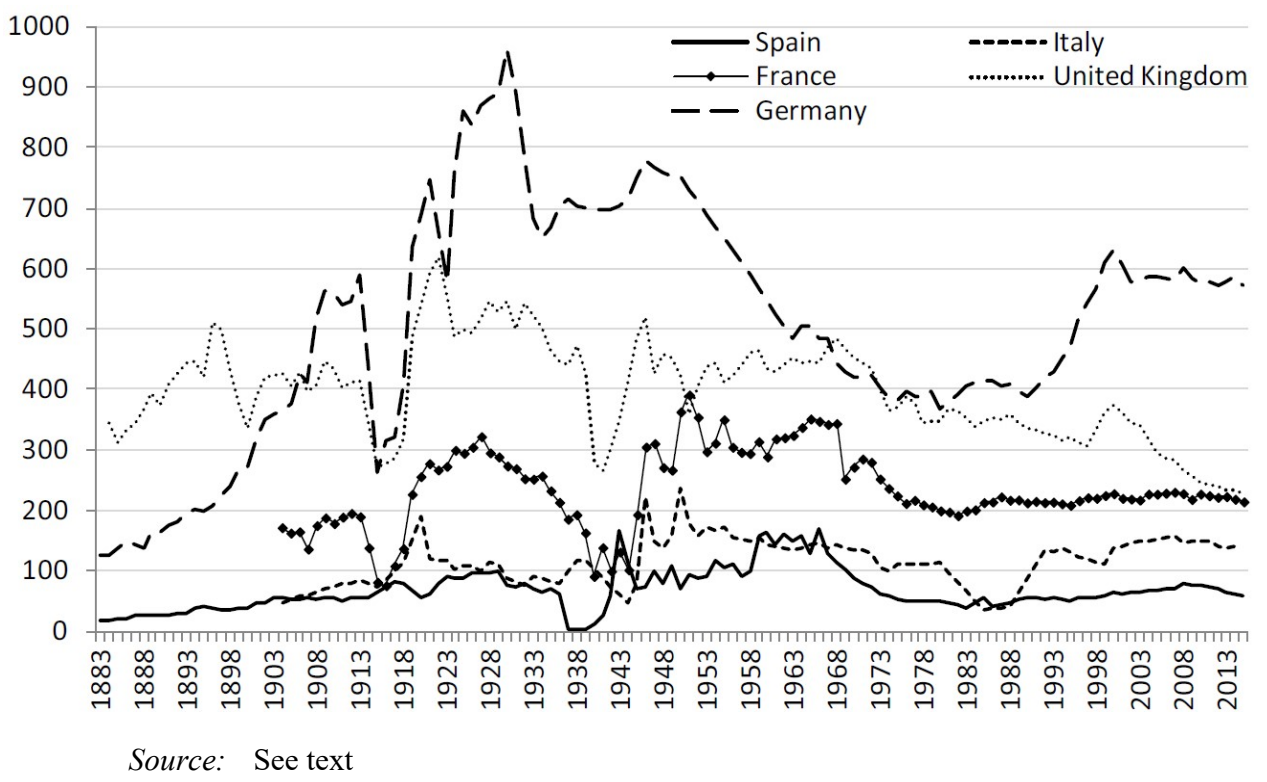

In short, the patents per capita filed in Spain by residents in the country indicate that the national innovative capacity grew since 1883 - with a strong setback in the 1930 s - up to reach its historical maximum in the late 1960s. After another deep setback in the 1970s, in the early 1980s they resumed an increasing trend which lasted up to 2008. According to the value of the indicator itself, the Spanish innovative capacity in the latter year would be the same as in 1917, which is not credible given the enormous modernisation experienced by the Spanish economy throughout the last century (e.g., Carreras and Tafunell, 2004; Tortella and Núñez, 2011). This is indicative of the inter-temporal comparability problems of this indicator just mentioned. As the patents granted in the USA do not have this problem, they seem a more reliable measure of the innovative capacity in the very long run. Therefore, according to this, Spain would have 
achieved its maximum innovative capacity at the beginning of the 21 st century. In any case, the indicator of patents filed in the country by its residents - taking into account that it probably does not reflect the same thing before and after 1966 - allows to capture several nuances that the other one does not show, as we have seen. As in the previous case, the comparison with other countries, in addition of providing some new evidence, will allow to assess the real performance of the country regarding our second indicator.

As with the previous indicator, the patents filed by residents in each country show a persistent backwardness of Spain compared to the largest nations in Western Europe in terms of innovative capacity from 1883 to 2015 (Figure 5). However, the order of magnitude of the disadvantage is much smaller according to this indicator than according to the patents granted in the USA (Figure 2). The German innovative capacity, which according to the latter has been normally 20 times as big as the Spanish one, in terms of patents filed in the country has been at the most (in the late 1920s and at the beginning of the 21 st century) nine times as big. The UK has been between four and six times more innovative than Spain, and France, between 2 and 3. Italy has had a level only slightly over the Spanish one and in some moments similar or even lower. On average, the 1960s was the period when Spain was closer to the innovative level of those countries.

In all five cases, this indicator has shown an increasing trend until reaching a maximum at some point in the 20th century, followed by a downward trend and a subsequent recovery, but only partial. As has been said, in the case of Spain that pivotal point was the year 1966, but in the other four cases it came earlier. The UK reached its maximum level in 1920, Germany in 1929, Italy in 1950, and France in 1951. The declining trend from those peaks reversed in the 1980s in all countries except in the UK, which is the only case where the level of 2015 was below the initial one (1883). The reversal was particularly strong in Germany and very weak in France. In any case, no country has recovered the maximum level achieved previously in the 20th century. ${ }^{14}$

This pattern is also observable in the USA. According to Gilfillan (1964, p.44), the peak of domestic patent applications in that country would have been reached in 1929, although Stafford placed it earlier, in 1914. Gilfillan saw in this phenomenon a fall in the ratio of patents to invention and observed that it was something that occurred in every developed country (ibid.). In fact, the data just given seem to indicate a certain relationship between the moment of the turning point and the level of economic development; that is, the more developed the country was, the earlier the change seemed to begin. This needs more evidence to be confirmed but, in any case, it is also necessary to identify the specific causes of the decrease in the propensity to patent. Some authors have highlighted the following: the increasing transfer of inventive activity from individuals to companies, which would be less needed than the previous ones to patent their inventions; the increase in the weight of research conducted or promoted by public and military institutions, largely non-patented; certain unfavourable court decisions for patent holders; the decrease of patents of non-relevant inventions thanks to an improvement in the scrutiny by the Patent Office; the increase of license agreements and patent pools between companies, etc. [Gilfillan, (1964), pp.41-44; Schmookler, 1966]. This explanation makes sense, but it would be necessary to verify the effect of the factors mentioned in the use of the patent system by the inventors of the different countries. Of course, this would require an investigation in its own right, which exceeds the purpose of this article. It is pertinent, however, to close this section with the comparison of the Spanish case with the Argentine and the Mexican as has been done in the previous one. 
Figure 6 Domestic patent applications in Argentina, Mexico and Spain per million inhabitants, $1883-2015$

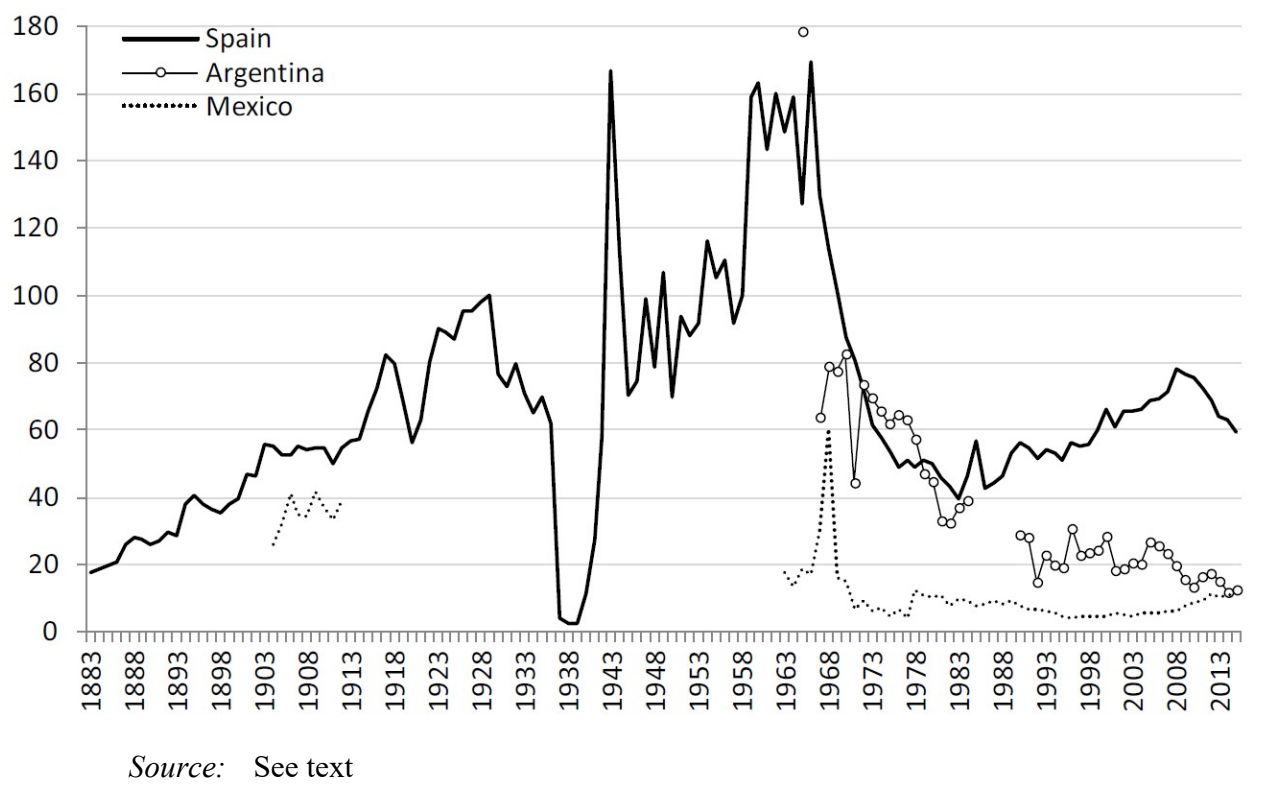

The WIPO historical database contains information on the patents registered by residents in Argentina and Mexico only since the 1960s, although it also covers an earlier short period (1904-1910) for the case of Mexico. ${ }^{15}$ Having this limitation in mind, the first evidence stemming from Figure 6 is that Mexico apparently had an innovative capacity lower than the Spanish one both at the beginning of the 20th century and since the 1960s onwards, the disadvantage being greater and increasing in the second period. This contrasts with the advantage shown by Mexico over Spain before 1930 according to the patents granted in the USA (Figure 3). The geographical proximity could have influenced in this, but other factors must have affected because in that indicator Argentina was over Mexico since the 1920s and Spain has also been clearly ahead of the latter since the 1960s in the two indicators. ${ }^{16}$ Argentina also fell behind Spain since 1960 with regard to patents granted in the USA (Figure 3), but had a similar level - and occasionally higher from then to the early 1980s in terms of domestic patents filed in the country (Figure 6). However, while the declining trend in the latter indicator reversed in Spain in that decade, it was maintained in Argentina. So, today, the two Latin American countries have not only moved considerably away from the Spanish level, but have also fallen to their lowest level ever. ${ }^{17}$ These data reinforce the aforementioned idea (Figure 3 ) that in those countries an historical reversal in the innovative capacity has occurred compared to the first third of the 20th century, whereas Spain has maintained an increasing trend in the last three decades, although interrupted by the 2008 crisis.

\section{Scientific publications}

The number of scientific publications per inhabitant is strictly speaking a measure of the scientific capacity but, as many of the findings of those publications are the basis of 
technological improvements with a commercial use, it is undeniable that such indicator is related to the innovative activity. This is why it has also been used as a measure of the national innovative capacity (Furman et al., 2002; Archibugi and Coco, 2005). ${ }^{18}$ It is certain that there are both scientific results with and without influence in the technological development, their relative proportion being unknown. Even so, it can be thought that scientific research - even that without practical application - helps to make a society more prone to innovation (Mokyr, 2002). This does not mean that every innovation comes from scientific activity [Mansfield, 1968; Geroski, (1994), p.23], so the number of publications would be in any case a partial and indirect indicator of the innovative capacity. Still, their analysis can give interesting clues, in addition of complementing patent data.

Figure 7 Scientific publications in Spain per million inhabitants, 1860-2017 (logarithmic scale)

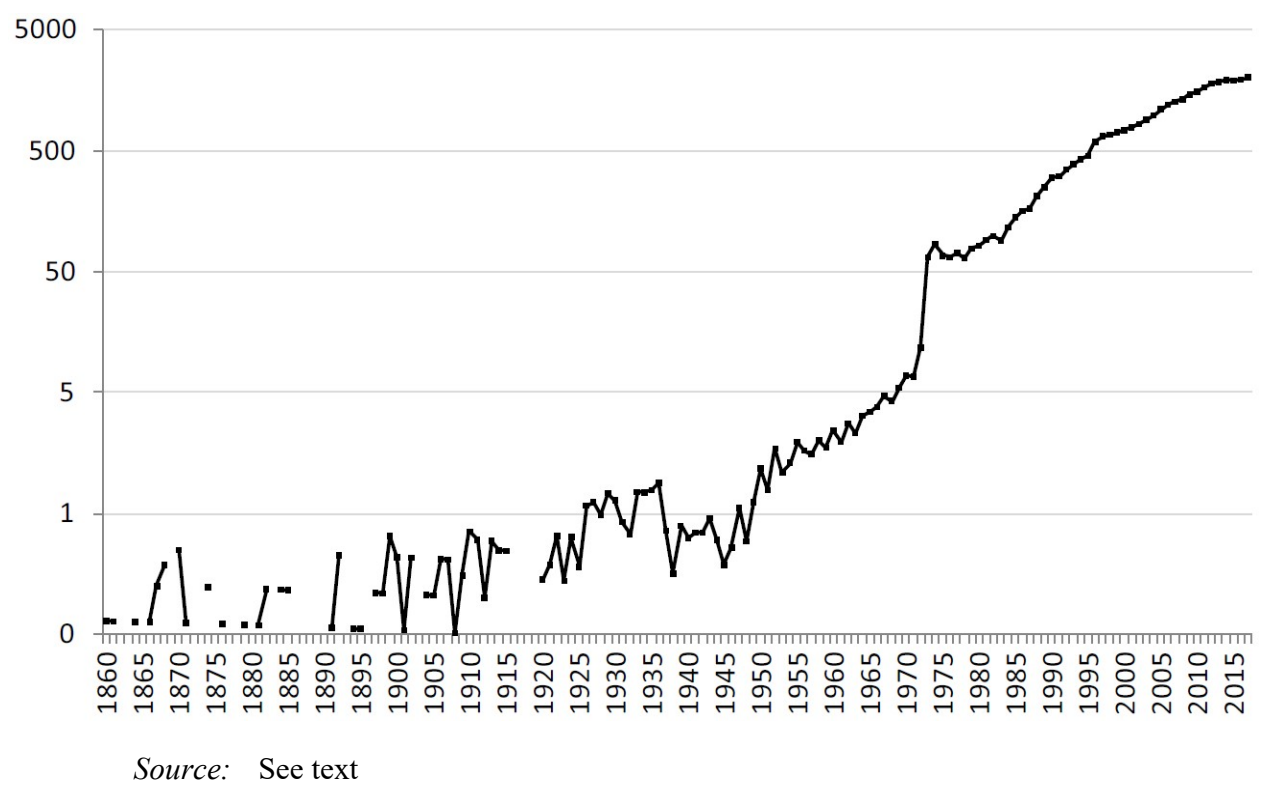

The Scopus database contains information on published works in many countries in all scientific areas since the 19th century to nowadays. There are other databases, but this is the broadest one, obviously without being complete. The data used in this study have been taken from it. ${ }^{19}$ As this is a first approach to the problem, we have opted for using the most general indicator ('all documents' in Scopus); that is, the number of publications in all scientific fields ${ }^{20}$ and document types (journals, books, chapters, working papers, etc.). Figure 7 shows the evolution of this indicator per million inhabitants for Spain since 1860 to 2017 . The quantitative leap from the mid-20th century onwards is so great, ${ }^{21}$ that the previous evolution can only be visualised if the data are taken in logarithms. This subtracts some realism (proportionality) from the graphic representation, but the main trends are clearly noticeable.

It can be observed in the first place that from 1860 to 1935 , with discontinuities and noticeable fluctuations due to the scarcity of data, there was a slow increasing trend of scientific publications in Spain. However, in that long period there were three declining phases: from 1870 to 1890 ; the first years of the 20th century; and the years around the 
First World War. As with most indicators, the Spanish Civil War (1936-1939) led to a drastic fall in scientific production, but in 1945 it resumed a growing trend that, with a slight and short fall in 1973, has lasted until today. In this second phase, the increase was particularly rapid in the 1940 s and early 1970s. If the evolution of this indicator is compared with that of patents, there is great similarity for the period before the Civil War, both for patents granted in the USA (Figure 1) and for national applications in the country (Figure 4). Its evolution is also by and large similar to that of the two patent variables from 1936 to 1970, but since then, it is much more similar to that of the patents granted in the USA than of the applications in the country. Yet, it has also certain similarity with the latter since 1983.

In general, the Spanish scientific production shows a clearly growing trend, and less fluctuating than the variables related with patents throughout the whole period, which is sign that it has been less affected than the latter by economic cycles. It seems, then, that the country has been able to develop a scientific structure that has gradually strengthened and increased its capacity without depending significantly on the economic ups and downs. Its lower sensitivity to these factors, circumstantial in many occasions, leads to think that the scientific production would provide a less distorted view than the other indicators on the evolution of the innovative capacity over time, in spite of being less adequate as a specific measure of the innovation activity. Like in the previous sections, the international comparisons will allow to assess the Spanish achievement in this regard.

Figure 8 Scientific publications in five European countries per million inhabitants, 1860-2017 (logarithmic scale)

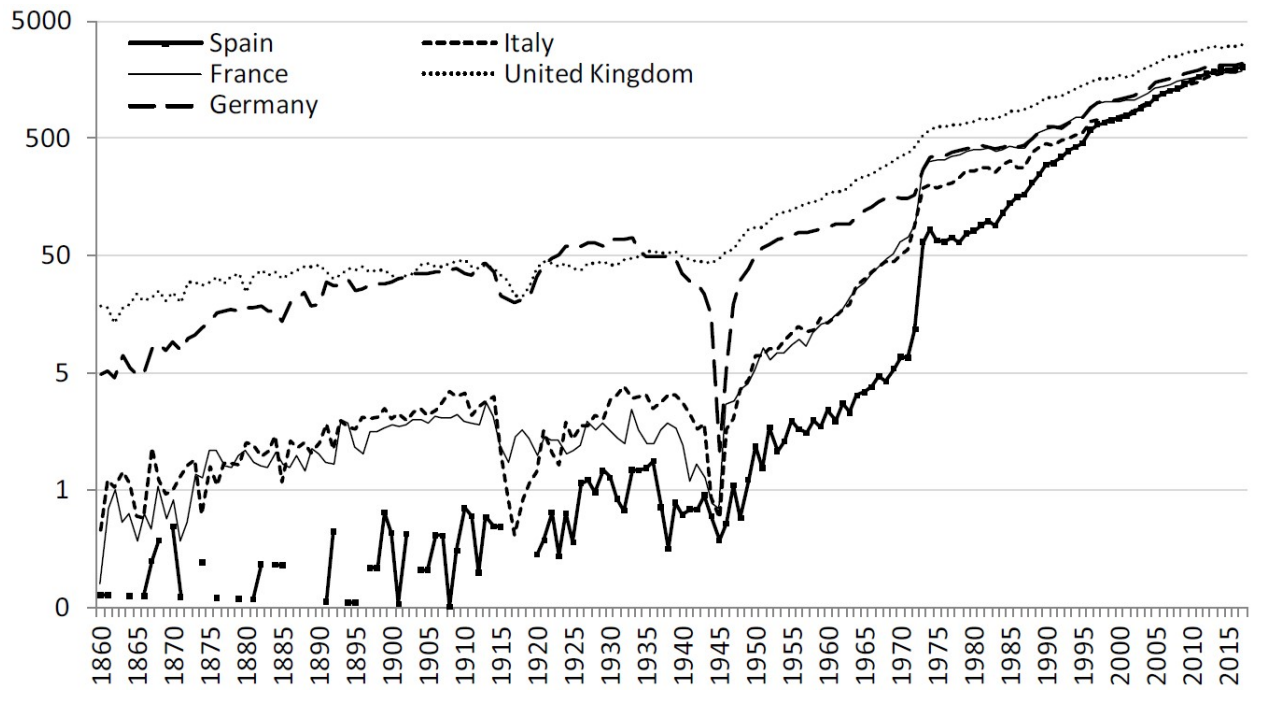

Source: See text

The comparison with the main countries of Western Europe shows that the scientific backwardness of Spain was very considerable until the 1970s, when the recovery process - previously very slow - accelerated to the point that today it has almost reached the level of those other countries (Figure 8). Thus, the main difference between the Spanish position in scientific production and in generation of patents is that while in the latter the country has not been able to catch up with Europe, in the former it is about to achieve it. ${ }^{22}$ 
This different performance reveals that the two variables reflect different things. However, it also invites to think that the scientific capacity (publications) influences the innovative one (patents) with a time lag. In this way, for instance, the fact that Italy passed from having at the beginning an innovative capacity similar and even slightly lower than the Spanish one to be systematically over it since the end of the 19th century (Figures 2 and 5), could be explained by its clear superiority in scientific production since 1860 (Figure 8). And the other way round, the fact that Spain has recently caught up with Italy in this aspect could explain why the distance between both countries is being reduced in terms of the generation of high-quality patents (Figure 2). Likewise, the greater advantage of the UK and Germany over Spain in scientific production fits well with their clear dominion in patents. However, the French case indicates that the innovative capacity (patents) would depend only partially on the scientific capacity as in this aspect that country has been normally (up to the 1970s) below Italy, whereas in patents per capita it has been always above it. Therefore, the innovative capacity would depend as well on other variables - like the level and/or type of education - and probably on the orientation - more or less practical - of the scientific system. Obviously, these are preliminary evidences which require a specific study. In any case, they seem plausible in addition of clarifying the logic behind the use of the scientific publications as indicator (indirect and partial) of the innovative capacity.

Figure 9 Scientific publications in Argentina, Mexico and Spain per million inhabitants, 1860-2017 (logarithmic scale)

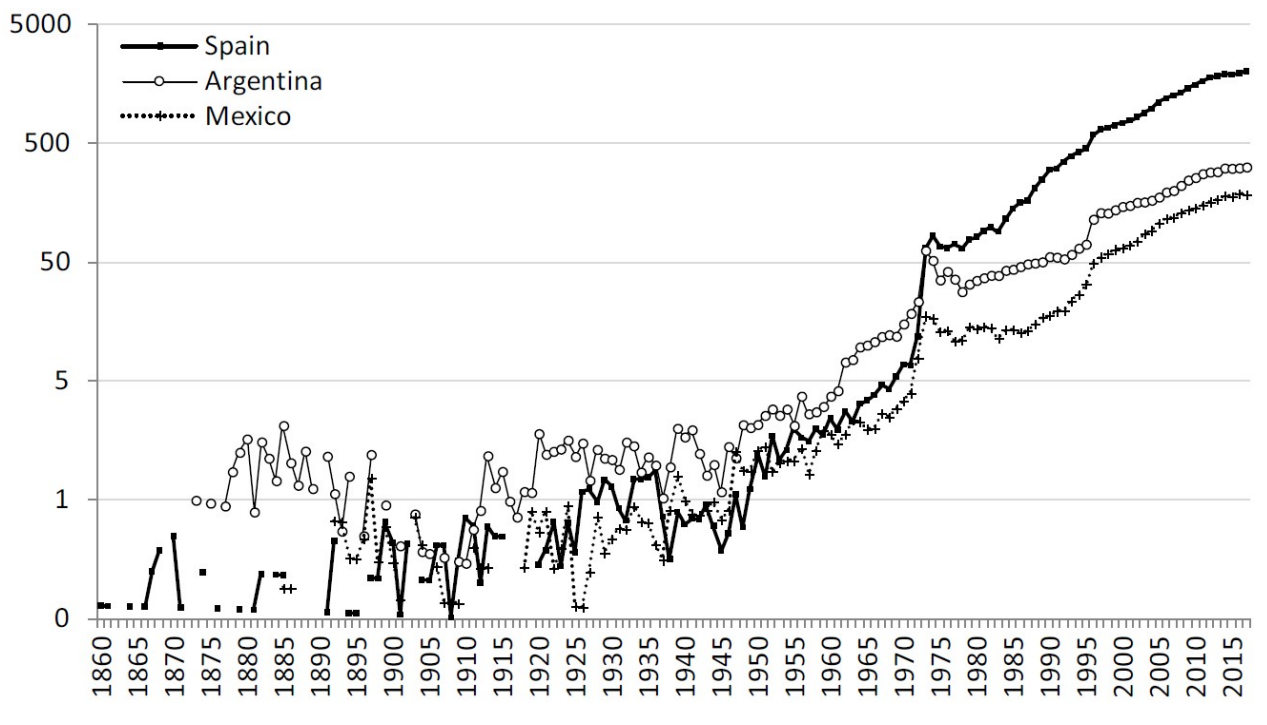

Source: See text

Lastly, the evolution of the number of publications per million inhabitants in Spain, Argentina and Mexico is presented in Figure 9. It shows that, as happened with the generation of patents (Figures 3 and 6), Argentina had a systematic advantage over Spain in scientific production up to 1970, when the situation reversed. Although not so clearly, the relative position of Spain and Mexico in both indicators also evolved by and large in a similar fashion. As has been shown, in terms of patents granted in the USA (Figure 3), 
Mexico was over Spain up to 1930 and also in the 1940s; in the 1950s both nations were at the same level; and since the 1960s, Spain took clearly the lead. This is also more or less the way in which the two countries evolved in terms of scientific production, although in this case Mexico's advantage over Spain before 1930 was clearly lower than in terms of patents granted in the USA, which probably can be explained by geographical proximity, particularly favourable to Mexico in that variable. In fact, Spain was always over Mexico regarding domestic patents filed in each country (Figure 6). Despite this, the influence of scientific production on patents is still noticeable because the minimum distance between Mexico and Spain in that variable occurred in the early 20th century, precisely when Mexico was slightly above Spain in terms of scientific publications per capita. Anyway, the advantage of Spain in domestic patent applications indicates, as happened with France, that the relation between scientific and innovative capacity would not be proportional. It is certain that the very existence of such a relationship must be demonstrated, but the evidence provided is at least sign of it. The rapid progress of Spain (and the convergence between Mexico and Argentina) in both indicators since the 1970s is other evidence in the same line.

\section{Conclusions and policy implications}

Most would probably accept without statistical evidence that in modern times some countries have been more innovative than others. Indeed, according to the production of innovations with global economic impact, undoubtedly the UK, Germany, France, the USA, Switzerland and Japan would be among the most innovative nations. More difficult is to explain why this has been so. In almost tautological terms, one could say that the greater the innovative capacity of a country, the more innovative it will be. Therefore, if we were able to measure the innovative capacity, we would have taken a step forward to understand the problem. But that would not be enough, since even more important is to understand how the innovative capacity is created or improved; that is, to identify what factors determine it and in what way. More or less explicitly, these questions have concerned many researchers for a while. But the specific effort to measure the innovative capacity and identify its determining factors is more recent.

In order to obtain a measure of the innovative capacity, some authors have used a single indicator and others have calculated a composite index. Whichever option is chosen, obtaining a measure of the innovative capacity is a necessary preliminary step to analyse its determinants. But, both quantifying the innovative capacity and identifying its determining factors are complex matters. In the present paper, an exploration into the former aspect has been carried out aiming to obtain a first general view on the evolution of the Spanish innovative capacity from the 19th century to this day. To that end, we have used three of the indicators used by previous studies; namely, the patents granted to Spaniards in the USA, the domestic patents filed in Spain, and the scientific publications produced in the country. A descriptive analysis of each indicator has been developed, highlighting at the same time the similarities and differences among them. In addition, a comparison with two groups of countries - from Western Europe and Latin America has been carried out in order to assess the real significance of the Spanish performance.

Although none of the three mentioned indicators is a perfect measure of the national innovative capacity, the study has provided some evidence - in line with previous research - that the number of patents per capita granted in the USA is probably the most 
adequate one or, rather, the less inadequate. But we have also shown that the other two variables provide valuable information not contained in the former. Hence, a better idea of the national innovative capacity will be obtained if all the three indicators are taken into account.

The first conclusion of the paper is that the Spanish innovative capacity has increased noticeably since the 19 th century to nowadays. Such increase has been greater according to the patents granted in the USA and the scientific publications than to the domestic patent applications. The worse performance of the latter can be at least partially explained by the fall in the propensity to patent in the own country - an international phenomenon probably related to the economic development - after a pivotal moment in the 20th century (the mid-1960s in the Spanish case), thus making the values of this indicator not comparable before and after that change. Even so, the three indicators coincide by and large in their fluctuations over time. According to this, the Spanish innovative capacity experienced a growing trend up to 1930 and, after a period of decline, resumed the increasing trend in the 1940 s up to the 2008 crisis, with only two short and slight downturns in the mid-1970s and in the early 1990s. Therefore, the innovative capacity evolved more or less in parallel to the economic development of the country. However, a careful look at the variables shows several short-term fluctuations over the years, the analysis of which must be addressed through more detailed studies.

The international comparisons have revealed the persistent backwardness of Spain's innovative capacity with respect to the main nations of Western Europe, but also a tendency to approach them, much more intense in terms of scientific publications than patents. On the other hand, Mexico was above Spain in terms of patents granted in the USA and scientific publications - not in domestic patents - up to 1930, and Argentina surpassed Spain in the three indicators up to 1960. But since then, both Argentina and Mexico began to fall behind, in such a way that nowadays Spain far exceeds the two Latin American nations in all the three measures. To sum up, Spain has been able to improve its innovative capacity over time and achieve a not bad position in the world context, but it is still far behind the most innovative nations. Therefore, the country needs to increase the effort made in recent decades if it wants to close that gap in the future; but also if it wants to maintain its international position, since there are several emerging countries that are already running faster. More worrying, however, seems the reversal experienced by Argentina and Mexico in their innovative capacity during the 20th century. Understanding the causes of this is a matter of great interest, which would be the object of another study.

These pages have presented a first general analysis of the long-term evolution of Spain's innovative capacity compared to other countries. Valuable ideas have been obtained, but many of a preliminary nature, which point to interesting topics for further research. A pending task is to identify the factors that have determined the innovative capacity over time and the patterns of that relationship. The specific implications for policymaking must await that study. However, some tentative ones may be derived from the present work.

By showing Spain's persistent backwardness in terms of innovative capacity compared to the European leaders, the study can help Spanish policy makers become more aware of the need to put science and technology policies at the forefront of their interests. In particular, it can help them realise that doing so - as they have not done so far - is essential to reduce the very high unemployment rate that the country has dragged 
on for decades. This would involve, among other things, creating adequate and more powerful institutional incentives to increase private investment in innovation. This is especially urgent at the moment, when estimates say that the coronavirus pandemic will drop Spanish GDP in 2020 between $8 \%$ and $13 \%$ and its unemployment rate increase to $22 \%$. The only way to reduce the impact of the crisis and achieve a rapid recovery is by promoting innovation to adapt the economy to the new situation that is emerging. However, the central government is rather thinking of introducing the universal basic income, which will make society more dependent on subsidies instead of being more innovative. The same mistake was made with the 2008 crisis, after which R\&D spending decreased in Spain - unlike in most European countries - and the unemployment rate grew to $25 \%$. In summary, this study can help policymakers learn from the past and understand that they need to increase, not weaken, the country's innovative capacity by implementing smart policies that involve public and private actors. ${ }^{23}$

In relation to Latin American countries, a first lesson for policymakers is that technological progress cannot be taken for granted: a reversal is possible as it has been in Argentina and Mexico since the 1960s. This is probably related to the institutional and financial instability that they went through in the last decades of the 20th century, with the consequent neglect of educational, scientific and technological policies. But the root of these problems lies in more fundamental causes, such as their high income inequality, their governments' focus on control rather than growth, their low endowment of skills, and the weak link between their scientific/educational and business spheres [von Tunzelmann, (1995), p.360 ff.]. Therefore, to regain the path of increasing innovative capacity, these countries need, firstly, institutional stability and, secondly, to reinforce and reconfigure their national innovation system. Particularly important at this stage is the initiative of governments to facilitate links between knowledge institutions (universities and R\&D centres) and companies due to the low innovative dynamism of the latter, as a study on Argentina recently pointed out (Pasciaroni et al., 2018). More generally, governments should focus on developing an institutional environment geared towards building national innovation capacities, such as China is doing successfully (Sawang et al., 2017). In fact, the East Asian modernisation experience can serve as inspiration for Latin American governments and entrepreneurs (e.g., Amsden, 1989; Bell and Figueiredo, 2012; von Tunzelmann, 1995).

\section{References}

Amsden, A.H. (1989) Asia's Next Giant: South Korea and Late Industrialization, Oxford University Press, New York.

Archibugi, D. and Coco, A. (2005) 'Measuring technological capabilities at the country level: a survey and a menu for choice', Research Policy, Vol. 34, No. 2, pp.175-194.

Beatty, E., Pineda, Y. and Sáiz, P. (2017) 'Technology in Latin America's past and present: new evidence from the patent records', Latin American Research Review, Vol. 52, No. 1, pp.138-149.

Bell, M. and Figueiredo, P.N. (2012) 'Building innovative capabilities in latecomer emerging market firms: some key issues', in Amann, E. and Cantwell, J. (Eds.): Innovative Firms in Emerging Market Countries, pp.24-109, Oxford University Press, Oxford.

Bulmer-Thomas, V. (2003) The Economic History of Latin America Since Independence, Cambridge University Press, Cambridge. 
Campa, J.I. (2018a) 'Naturaleza y efectos de la política de patentes en el régimen de industrialización por sustitución de importaciones en México entre 1940 y 1970', Revista de Historia Económica - Journal of Iberian and Latin American Economic History, Vol. 36, No. 3, pp.363-392.

Campa, J.I. (2018b) 'Patentes y desenvolvimiento tecnológico en México: un estudio comparativo entre la época de industrialización proteccionista y el régimen de apertura', América Latina en la Historia Económica - Latin America in Economic History, Vol. 25, No. 3, pp.223-257.

Camprubí, L. (2014) Engineers and the Making of the Francoist Regime, The MIT Press, Cambridge, Mass. and London.

Carreras, A. and Tafunell, X. (2004) Historia económica de la España contemporánea, Barcelona, Crítica.

Cebrián Villar, M. (2001) 'Las fuentes del crecimiento económico español, 1964-1973', Revista de Historia Económica - Journal of Iberian and Latin American Economic History, Vol. 19, No. 1, pp.277-299.

Clò, S., Florio, M., Pellegrin, J. and Sirtori, E. (2018) 'How do research intensive systems emerge in less developed areas? The case of mechatronics in the Italian southern region Apulia', International Journal of Technological Learning, Innovation and Development, Vol. 10, No. 1, pp.1-36.

Cotropia, C.A., Quillen, C.D. and Webster, O.H. (2013) Patent Applications and the Performance of the U.S. Patent and Trademark Office, Richmond School of Law Intellectual Property Institute Research Paper No. 2013-01.

Cubel, A., Esteve, V., Sanchís, J.A. and Sanchís, M.T. (2012) 'Medio siglo de innovación y transferencia de tecnología en España, 1950-2000', Revista de Historia Industrial, Vol. 50, No. 3, pp.113-154.

Desai, M., Fukuda-Parr, S., Johansson, C. and Sagasti, F. (2002) 'Measuring the technology achievement of nations and the capacity to participate in the network age', Journal of Human Development, Vol. 3, No. 1, pp.95-122.

Deu, E. and Llonch, M. (2013) 'Autarquía y atraso tecnológico en la industria textil española, 1939-1959', Investigaciones de Historia Económica - Economic History Research, Vol. 9, No. 1, pp.11-21.

Eaton, J. and Kortum, S. (1996) 'Trade in ideas: patenting and productivity in the OECD', Journal of International Economics, Vol. 40, Nos. 3-4, pp.251-278.

Eaton, J. and Kortum, S. (1999) 'International technology diffusion: theory and measurement', International Economic Review, Vol. 40, No. 3, pp.537-570.

Fernández Pérez, P., Puig, N., García-Canal, E. and Guillén, M.F. (2019) 'Learning from giants: early exposure to advance markets in the growth and internationalisation of Spanish health care corporations in the twentieth century', Business History, Vol. 61, No. 3, pp.404-428.

Furman, J., Porter, M. and Stern, S. (2002) 'The determinants of national innovative capacity', Research Policy, Vol. 31, No. 6, pp.99-933.

German-Soto, V. and Chapa Cantú, J.C. (2018) 'Structural change in the international patenting level: the TRIPs agreement's role', International Journal of Technological Learning, Innovation and Development, Vol. 10, No. 2, pp.131-158.

Geroski, P.A. (1994) Market Structure, Corporate Performance and Innovative Activity, Clarendon Press, Oxford.

Gilfillan, S.C. (1964) Invention and the Patent System. Materials Relating to Continuing Studies of Technology, Economic Growth, and the Variability of Private Investment Presented for Consideration of the Joint Economic Committee, Congress of the United States, United States Government Printing Office, Washington, DC.

Griliches, Z. (1990) 'Patent statistics as economic indicators: a survey', Journal of Economic Literature, Vol. 28, No. 4, pp.1661-1707. 
Grossman, G. and Helpman, E. (1991) Innovation and Growth in the Global Economy, MIT Press, Cambridge, MA.

Hofman, A.A. (2000) The Economic Development of Latin America in the Twentieth Century, Edward Elgar, Cheltenham, UK and Northampton, MA, USA.

Instituto Nacional de Estadística (INE) [online] https://www.ine.es/ (accessed December 2018).

James, J. and Romijn, H. (1997) 'The determinants of technological capability: a cross-country analysis', Oxford Development Studies, Vol. 25, No. 2, pp.189-207.

Kruss, G. (2018) 'Towards an agenda for measuring innovation in emerging African economies: what can we learn from the case of South Africa?', International Journal of Technological Learning, Innovation and Development, Vol. 10, Nos. 3-4, pp.347-365.

Lall, S. (1992) 'Technological capabilities and industrialization', World Development, Vol. 20, No. 2, pp.165-186.

Landes, D.S. (1969) The Unbound Prometheus: Technological Change and Industrial Development in Western Europe from 1750 to the Present, Cambridge University Press, Cambridge.

López, S. and Valdaliso, J.M. (1997) ¿Que inventen ellos? Tecnología, empresa y cambio económico en la España contemporánea, Alianza Editorial, Madrid.

López, S. and Valdaliso, J.M. (2001) 'Cambio tecnológico y crecimiento económico en España en la segunda mitad del siglo XX: indicadores y polémicas', Revista de Historia Industrial, Vols. 19-20, No. 1, pp.319-337.

Maddison Project Database, Bolt, J., Inklaar, R., de Jong, H. and van Zanden, J.L. (2018) Rebasing 'Maddison': New Income Comparisons and the Shape of Long-run Economic Development, Maddison Project Working Paper No. 10.

Maddison, A. (2001) The World Economy: a Millennial Perspective, OECD, Paris.

Maluquer-de-Motes, J. (1987) 'De la Crisis Colonial a la guerra europea: veinte años de economía española', in Nadal, J., Carreras, A. and Sudrià, C. (Eds.): La economía española en el siglo XX. Una perspectiva histórica, pp.62-104, Ariel, Barcelona.

Mansfield, E. (1968) Industrial Research and Technological Innovation: an Econometric Analysis, Norton, New York.

Mokyr, J. (1990) The Lever of Riches. Technological Creativity and Economic Progress, Oxford University Press, New York and Oxford.

Mokyr, J. (2002) The Gifts of Athena: Historical Origins of the Knowledge Economy, Princeton University Press, Princeton and Oxford.

Moser, P. (2012) 'Innovation without patents: evidence from world's fairs', The Journal of Law and Economics, Vol. 55, No. 1, pp.43-74.

Narula, R. (2004) Understanding Absorptive Capacities in an 'Innovation Systems' Context: Consequences for Economic and Employment Growth, DRUID Working Paper No. 04-02.

Nelson, R.R. (1993) National Innovation Systems: a Comparative Analysis, Oxford University Press, New York.

Nicolau, R. (2005) 'Población, salud y actividad', in Carreras, A. and Tafunell, X. (Eds.): Estadísticas históricas de España. Siglos XIX-XX, Vol. 1, Capítulo 2, pp.77-154, Fundación BBVA, Bilbao.

Nuvolari, A. and Vasta, M. (2015) 'The ghost in the attic? The Italian national innovation system in historical perspective, 1861-2011', Enterprise \& Society, Vol. 16, No. 2, pp.270-290.

Ortiz-Villajos, J.M. (1999) Tecnología y desarrollo económico en la historia contemporánea. Estudio de las patentes registradas en España entre 1882 y 1935, Oficina Española de Patentes y Marcas, Madrid.

Ortiz-Villajos, J.M. (2004) 'Spain's low technological level: an explanation', in Ljungberg, J. and Smits, J-P. (Eds.): Technology and Human Capital in Historical Perspective, pp.182-204, Palgrave Macmillan, Houndmills-New York.

Ortiz-Villajos, J.M. (2009) 'Patents and economic growth in the long term. a quantitative approach', Brussels Economic Review, Vol. 52, Nos. 3-4, pp.305-340. 
Ortiz-Villajos, J.M. (2016) Cotec, 1990-2015. Un cuarto de siglo impulsando la innovación, Fundación Cotec para la Innovación, Madrid.

Ortiz-Villajos, J.M. (2017) 'Forms of innovation throughout time: insights from the British business elite', Innovation: Organization \& Management, Vol. 19, No. 4, pp.428-451.

Pasciaroni, C., Gorenstein, S. and Barbero, A. (2018) 'Knowledge organisations in less innovative regions: what factors explain the emergence and development of their links with firms? A case study in Argentina', International Journal of Technological Learning, Innovation and Development, Vol. 10, No. 1, pp.88-112.

Porter, M.E. (1990) 'The competitive advantage of nations', Harvard Business Review, Vol. 68, No. 2, pp.73-93.

Prados-de-la-Escosura, L. and Rosés, J.R. (2009) 'The sources of long-run growth in Spain, 1850-2000', The Journal of Economic History, Vol. 69, No. 4, pp.1063-1091.

Romer, P.M. (1990) 'Endogenous technological change', The Journal of Political Economy, Vol. 98, No. 5, pp.S71-S102.

Sáiz, J.P. (1999) Invención, Patentes e Innovación en España (1759-1878), Oficina Española de Patentes y Marcas, Madrid.

Sáiz, J.P. (2005) 'Investigación y desarrollo: patentes', in Carreras, A. and Tafunell, X. (Eds.): Estadísticas históricas de España. Siglos XIX-XX, Vol. 2, Capítulo 11, pp.835-872, Fundación BBVA, Bilbao.

Sanders, B.S. (1962) 'Some difficulties in measuring inventive activity', in National Bureau of Economic Research (Ed.): The Rate and Direction of Inventive Activity: Economic and Social Factors, pp.53-77, Princeton University Press, Princeton.

Sawang, S., Zhou, Y. and Yang, X. (2017) 'Does institutional context matter in building innovation capability?', International Journal of Technological Learning, Innovation and Development, Vol. 9, No. 2, pp.153-168.

Schmookler, J. (1962) 'Comment to sanders', in National Bureau of Economic Research (Ed.): The Rate and Direction of Inventive Activity: Economic and Social Factors, pp.78-83, Princeton University Press, Princeton.

Schmookler, J. (1966) Invention and Economic Growth, Harvard University Press, Cambridge, Mass.

Schumpeter, J.A. (1934) The Theory of Economic Development. An Inquiry into Profits, Capital, Credit, Interest, and the Business Cycle, Harvard University Press, Cambridge, MA.

Scopus Database [online] https://www.scopus.com (accessed December 2018).

Solow, R.M. (1957) 'Technical change and the aggregate production function', The Review of Economics and Statistics, Vol. 39, No. 3, pp.312-320.

Tortella, G. and Núñez, C.E. (2011) El desarrollo de la España contemporánea. Historia económica de los siglos XIX y XX, Alianza Editorial, Madrid.

United Nations Development Program (UNDP) (2001) Human Development Report 2001. Making New Technologies Work for Human Development, Oxford University Press, New York [online] http://www.undp.org (accessed July 2017).

United States Patent and Trademark Office (USPTO) (1977) Technology Assessment \& Forecast, Seventh Report, March, US Department of Commerce.

USPTO Database [online] https://www.uspto.gov/patents-application-process/search-patents (accessed December 2018).

Virós, L. (2013) 'Empresa e innovación tecnológica en el distrito industrial de Manresa durante el franquismo. Entre la copia, la adaptación y la creatividad', Investigaciones de Historia Económica - Economic History Research, Vol. 9, No. 1, pp.22-31.

Von Tunzelmann, G.N. (1995) Technology and Industrial Progress: the Foundations of Economic Growth, Edward Elgar, Cheltenham, UK and Lyme, USA.

World Intellectual Property Organization (WIPO) Database [online] https://www.wipo.int/ ipstats/en/ (accessed December 2018). 


\section{Notes}

1 Although it can be less adequate for the analysis of the innovative capacity of developing countries given their lower technological level (e.g., Bell and Figueiredo, 2012).

2 The data on patents granted in the USA to foreign residents have been obtained from United States Patent and Trademark Office (USPTO) (1977) for the period 1883 to 1976 and from the USPTO Database (https://www.uspto.gov/patents-application-process/search-patents) from 1977 to this day. The data on the Spanish population have been obtained from Nicolau (2005) up to 2000 and from the INE (https://www.ine.es/) database from then onwards. Population data on the rest of the countries have been obtained from the Maddison Project Database (2018).

3 This is less clear since 2009, reason why we do not go beyond that year in the analysis of this variable. For an explanation on the exponential (and spurious) rise of the patents granted in the USA in the last years, see, for instance, Cotropia et al. (2013).

4 For a detailed explanation on this, see Furman et al. (2002, p.909) or Eaton and Kortum (1996, 1999).

5 For a classic discussion on the limitations of patents as economic indicators, see Griliches (1990). For empirical evidence on the predominance of non-patented innovations, see Moser (2012) and Ortiz-Villajos (2017).

6 The Spanish Civil War (1936-1939) and the Second World War (1939-1945).

7 Actually, the disadvantage with Italy started in the 1890s, but it was not important before the Italian take-off after the Second World War.

8 For an analysis of the Latin American 'failure' compared to the 'East Asian miracle' with a special focus on the technological aspect, see von Tunzelmann (1995), Chapter 11.

9 For two overviews of the factors explaining the economic performance of Latin America in the 20th century, see Bulmer-Thomas (2003) and Hofman (2000).

10 The data on domestic patent applications in Spain have been obtained from Sáiz (2005) and Ortiz-Villajos (1999) up to 2000 and from the World Intellectual Property Organization (WIPO) Database (https://www.wipo.int/ipstats/en/) since then onwards. Patent data on the other countries have been obtained from the WIPO database. For data on population, see footnote 2.

11 As has been documented for 19th century Spain (Sáiz, 1999).

12 The effect of the depression is perceived since 1931 in the patents granted in the USA, whereas the patents applied for in Spain were affected already in 1929. This time lag - which is observed along the whole graph - is due to the fact that patent applications in the USA take normally between two and three years to be granted. This is the reason why patent applications are more adequate than patents granted to analyse the relation between patent data and the economic situation.

13 The anomalous peak at the beginning of the 1940s is explained by the accumulation of pending applications due to the administrative halt during the Civil War (1936-1939).

14 For an analysis of the structural change in the level of patents worldwide since 1963, see German-Soto and Chapa Cantú (2018).

15 More complete and detailed historical patent statistics of several Latin American countries are under construction (Beatty et al., 2017).

16 Institutional inefficiency has been highlighted as a key determinant of the failure of the Mexican patent system from 1940 to 1970 (Campa, 2018a). The same pattern - dominion of foreign patents and a weak domestic innovative capacity - has persisted in the period 1995-2015 (Campa, 2018b).

17 Although it cannot be said with certainty due to the lack of data, from Figure 6 it follows that in the case of the two Latin American countries there was also, as in the advanced ones, a turning point in the propensity to patent at the end of the 1960s. However, the decline since then has been so pronounced that it seems to have been due not only to a change in the 
propensity to patent but also to a loss of internal technological level. However, this is an interpretation that must be verified with more detailed research.

18 More than 50 years ago, in his famous report, Gilfillan (1964) already considered that science was an input of inventive activity and used the number of scientific publications as an indicator of the growth of the American invention between 1880 and 1960.

19 The data on the scientific publications of all countries included in the study have been obtained from the Scopus Database (https://www.scopus.com). For data on population, see footnote 2 .

20 By contrast, Nuvolari and Vasta (2015) use only data on publications in experimental sciences.

21 It must be taken into account that the database is probably more incomplete in the earlier periods.

22 It is true that the indicator used is crude, as it neither discriminates by scientific fields nor quality of the publications. In fact, when the variable is weighted by a quality measure (like the number of citations), the distance between Spain and the most developed countries is higher. Nevertheless, it is also diminishing [see Ortiz-Villajos, (2016), pp.234-241].

23 An example of this type of policy is the one implemented in Apulia, a disadvantaged area in Southern Italy, where a regional innovation system has been established in the mechatronics cluster at the joint initiative of the central government and local actors through the promotion of the interaction between companies and universities (Clò et al., 2018). 